\title{
The financial investigation of human trafficking in the UK: legal and practical perspectives
}

\author{
Ben Middleton*, Georgios A. Antonopoulos \& Georgios Papanicolaou \\ (Teesside University, UK)
}

Keywords: Trafficking victims; slavery; confiscation; asset seizure; compensation;

\begin{abstract}
A significant body of law and policy has been directed to organised crime generally, with Human Trafficking remaining high on the political agenda. This article conducts a contextualised study of Human Trafficking in the UK, examining the underpinning legal framework before drawing on the expertise of key professionals in the sector, who have been interviewed for this purpose. It is suggested that it is not so much the legal framework that is the problem, but rather there are a number of practical and policy-related considerations that the government should consider as part of their efforts to combat Modern Slavery and Human Trafficking.
\end{abstract}

\section{Introduction}

Finances of organised crime have been an increasingly important policy concern nationally and internationally. ${ }^{1}$ According to the Home Office, the revenue derived from organised crime is bigger than $£ 11$ billion per year, while the attendant economic and social costs are approximately $£ 25$ billion. $^{2}$ Modern slavery, including labour exploitation, sexual exploitation and domestic servitude, which according to the NCA affects "every large town and city in the country", ${ }^{3}$ is estimated to cost the UK between $£ 3.3 \mathrm{bn}$ and $£ 4.3 \mathrm{bn} .{ }^{4}$ The British Government has stated its determination to deal with organised crime finances, including the finances of human trafficking by:

- dealing with the "substantial illegal profits for traffickers and slave drivers";,

- "attack[ing] the profits of traffickers and slave drivers through greater use of asset recovery and financial investigation ';

\footnotetext{
${ }^{1}$ See Levi, M. and Osofsky, L. (1995) Investigating, Seizing and Confiscating Proceeds of Crime. London: Home Office; Levi, M. (2013) Drug Law Enforcement and Financial Investigation Practices. London: IDPC; van Duyne, P.C. \& Levi, M. (2005) Drugs and Money. London: Routledge; Centre for the Study of Democracy (2015) Financing of Organised Crime. Sofia: Centre for the Study of Democracy; Antonopoulos, G.A. \& Hall, A. (2016) 'The Financial Management of the Illicit Tobacco Trade in the United Kingdom', British Journal of Criminology, 56(4), 709-728

${ }^{2}$ see Dubourg, R., \& Prichard, S. (2008). Organised crime: revenues, economic and social costs, and criminal assets available for seizure. London: Home Office; Mills, H., Skodbo, S., \& Blyth, P. (2013) Understanding organised crime: estimating the scale and the social and economic costs. London: Home Office.

${ }^{3}$ The Independent (2017) 'Human trafficking and slavery affecting 'every large town and city in UK', The Independent, August 102018.

${ }^{4}$ Home Office (2016) 'Home Secretary pledges $£ 11$ million for groups fighting modern slavery'. Available online at: https://www.gov.uk/government/news/home-secretary-pledges-11-million-forgroups-fighting-modern-slavery

${ }^{5}$ HM Government, 2014, 'Modern Slavery Strategy 2014'; available online at https://www.bl.uk/collection-items/modern-slavery-strategy 11.
} 
- defeating “human trafficking's vile and systematic international business model"; and

- $\quad$ taking steps to ensure that modern slavery does not reward offenders. ${ }^{8}$

Legislators have long attempted to disrupt the financing of human trafficking and slavery, and the UK now has a vast array of tools available to investigators to support disruption, criminalisation, and potentially confiscation of assets. ${ }^{9}$ There has also been a recent focus on the provision of reparations to victims: the UK Annual Report on Modern Slavery asks, inter alia, what the barriers are to effective seizure and of illicit profits made through modern slavery, and whether 'victims [are] receiving adequate financial compensation through civil and criminal routes'. ${ }^{10}$ The purpose of this article is to provide initial observations on these issues, assessing the extent to which the stated intent of the government is being achieved in reality.

Set against the legal background, this study is based firstly on a programme of semistructured interviews with 20 key informers, individuals who are well placed to have solid knowledge of this issue area. These include academic researchers working on 'organised crime' in general and human trafficking in particular, members of NGOs (e.g. Barnardo's and ECPAT -Every Child Protected Against Trafficking UK), law enforcement agents from the British Police, the National Crime Agency (NCA), the Gangmasters and Labour Abuse Authority (GLAA), HM Revenue and Customs (HMRC), Regional Special Operations Units, a criminal and financial investigations officer from the Home Office, as well as an officer from the Social Services. ${ }^{11}$

Secondly, intelligence reports by the Metropolitan Police were used. These intelligence reports are essentially problem profiles on either human trafficking in particular or 'organised crime' in general with the purpose to inform tactical tasking and coordinating groups within the police. Finally, open sources on the topic have been used in order to gain a better understanding of the business models in the human trafficking business in general. Such open source material includes reports by academics, research institutes, the government (Home Office), national and international law enforcement agencies (British Police, NCA, Scottish Crime and Drug Enforcement Agency (SCDEA), ${ }^{12}$ the GLAA, Europol, etc.), reports by international organisations (United Nations Office on Drugs and Crime (UNODC), Financial Action Task Force (FATF)), and NGOs. Open sources include media sources and press releases from law enforcement agencies.

\footnotetext{
${ }^{6} \mathrm{HM}$ Government (2015) Report of the inter-departmental ministerial group on modern slavery 2015 London: HMSO 22.

${ }^{7}$ May, T. (2016) 'My Government will lead the way in defeating modern slavery ', The Telegraph, July 30 ,

${ }^{8}$ HM Government, 2014, 'Modern Slavery Strategy 2014'; available online at https://www.bl.uk/collection-items/modern-slavery-strategy.

${ }^{9}$ The Proceeds of Crime Act 2002 (as amended) provides the majority of the legal framework and is examined below.

${ }^{10}$ HM Government (2018), 2018 UK Annual Report on Modern Slavery. Available online at: https://assets.publishing.service.gov.uk/government/uploads/system/uploads/attachment_data/file/749 346/2018_UK_Annual_Report_on_Modern_Slavery.pdf.

${ }^{11}$ Interviewees were promised anonymity. Antonopoulos conducted all interviews and holds details on file.

${ }^{12}$ SCDEA dissolved in 2013.
} 


\section{The framework of financial investigation of human trafficking}

The legal framework governing Human Trafficking is underpinned by the Proceeds of Crime Act 2002, which covers criminal confiscation, civil recovery of assets, cash forfeiture and criminal taxation. ${ }^{13}$ The 2002 Act has been continually amended by legislation including the Policing and Crime Act 2009, the Crime and Courts Act 2013, the Serious Crime Act 2015 and the Criminal Finances Act 2017, with changes to provisions made by virtue of the UK's opt in to EU Directive on preventing and combating trafficking in human beings and protecting its victims. ${ }^{14}$ Given the nature of Human Trafficking, Money Laundering provisions may also be engaged. ${ }^{15}$ Following the Modern Slavery Strategy in 2014, the Modern Slavery Act 2015 created a new offence of slavery, servitude and forced or compulsory labour, codified the offence of human trafficking, and created a new preparatory offence in relation to human trafficking. ${ }^{16}$ These steps were part of an intended 'comprehensive, cross-Government approach'. ${ }^{17}$

The Proceeds of Crime Act 2002 is expansive and provides for a variety of orders that can be used for investigative purposes as part of both civil and criminal proceedings. Orders can be requested by appropriate officers, which for a criminal confiscation investigation comprise NCA officers, accredited financial investigators, constables, SFO officers, officers of HM Revenue and Customs, and immigration officers. ${ }^{18}$ NCA officers, its Director, Revenue and Customs officers, or Financial Conduct Authority officers are also appropriate officers for the purposes of a civil recovery investigation. ${ }^{19}$

\section{Investigative orders}

Investigative orders include: disclosure orders, used to gather relevant information during an investigation, authorising investigators to compel an individual to answer questions, provide information or produce documents $;{ }^{20}$ production orders, granted to compel an individual to hand over specific material to investigating authorities, ${ }^{21}$ customer information orders, which can be requested to compel financial institutions to release information on a particular client, such as name, address, and date of birth and account numbers, as well as confirming whether or not a particular client holds or held an account at that financial institution; ${ }^{22}$ and account monitoring orders, though which financial institutions can be required to disclose all accounts held by a particular client, ${ }^{23}$ including joint accounts. ${ }^{24}$ Relevant Directors or senior

\footnotetext{
${ }^{13}$ The analysis of this article will focus chiefly on the legal systems of England and Wales, although the Proceeds of Crime Act 2002 makes analogous provision for Northern Ireland and Scotland.

${ }^{14}$ Directive 2011/36/EU.

${ }^{15}$ Part 7 POCA 2002.

${ }^{16}$ Respectively ss.1, 2 and 4 Modern Slavery Act 2015.

${ }^{17}$ HM Government, 2014, 'Modern Slavery Strategy 2014'; available online at https://www.bl.uk/collection-items/modern-slavery-strategy 9.

${ }^{18}$ S. 378 POCA 2002.

${ }^{19}$ S. 378(3) POCA 2002.

${ }^{20}$ Ss. 357-362 POCA 2002.

${ }^{21}$ Ss 345-351 POCA 2002.

${ }^{22}$ Ss. 363-369 POCA 2002.

${ }^{23}$ Ss. 370-375 POCA 2002.

${ }^{24}$ S. 370(4) POCA 2002.
} 
appropriate officers can request overseas assistance (for example, to another government or court in another jurisdiction) when seeking evidence in an ongoing investigation. ${ }^{25}$

This range of investigative tools have recently been supplemented by the introduction of Unexplained Wealth Orders (UWO). UWOs provide a civil investigative power that can require individuals who appear to hold property (valued over $£ 50,000$ ) disproportionate to their income to disclose their property assets and explain how the purchasing cost was met, paving the way for civil recovery of the assets. ${ }^{26}$ This reverse burden of proof ${ }^{27}$ strengthens the hand of investigators, but while it is clear that UWOs may eventually prove to be significant additions to a financial investigator's armoury, ${ }^{28}$ it is unlikely that they will play a leading role in the investigation of Human Trafficking.

\section{Recovery orders}

In addition to the investigative powers are a set of orders that are designed to recover the proceeds of a crime. Confiscation orders may be imposed after conviction, to confiscate assets gained through criminal activity from offenders, with the aim being to recover financial benefit that an offender has obtained from his conduct. ${ }^{29}$ Section 6 of the 2002 Act governs the regime to be imposed by the Crown Court. If the prosecutor seeks an order, or the court believes it is appropriate to impose one, ${ }^{30}$ it must usually decide whether the defendant has a criminal lifestyle and whether he has benefited from his general criminal conduct. ${ }^{31}$ Human Trafficking falls within the criminal 'lifestyle offences' listed in Schedule 2 of the Proceeds of Crime Act 2002. Section 7 of the Modern Slavery Act 2015 added slavery, servitude and forced labour to this list; it follows that confiscation orders can be made in cases associated with Human Trafficking.

In order to give further effect to this regime, the 2002 Act allows for restraint orders to be imposed by the Crown Court to freeze property that may be liable to confiscation following a trial, at any time once the investigation has commenced. ${ }^{32}$ There is a power to retain seized property, subject to a right to appeal. ${ }^{33}$ Search and seizure powers are provided: appropriate officers can exercise these powers in order to prevent the dissipation of realisable property. ${ }^{34}$ Conditions for the use of these powers are specified ${ }^{35}$ and are covered by a broad-ranging Code of Practice. ${ }^{36}$ The Act makes provision for the appointment of management receivers, ${ }^{37}$ enforcement receivers, ${ }^{38}$ and generally provides for the treatment of the seized assets.

\footnotetext{
${ }^{25}$ S. 375A POCA 2002.

${ }^{26}$ SS. 362 (A-C) POCA 2002.

${ }^{27}$ SS. 362C(1) \& (2) POCA 2002.

${ }^{28}$ Sproat, P. (2018) 'Unexplained wealth orders: an explanation, assessment and set of predictions', Journal of Criminal Law, 82(3), 232-244.

${ }^{29}$ ( $R$ v May (Raymond George) [2008] UKHL 28; [2008] 1 AC 1028).

${ }^{30}$ s. 6(3) POCA 2002.

${ }^{31}$ Ibid s. 6(4).

${ }^{32}$ Ibid ss. 40-41.

${ }^{33}$ Ibid ss. $41 \mathrm{~A}-44$.

${ }^{34}$ Ibid s. 47A-R.

${ }^{35}$ Ibid s. 47B.

${ }^{36}$ Home Office (2018) 'CODE OF PRACTICE ISSUED UNDER SECTION 47S OF THE PROCEEDS OF CRIME ACT 2002 Search, Seizure and Detention of Property (England and Wales)'. Available online at:
} 
Where there is a conviction for a Human Trafficking offence, therefore, the court can assume that the entirety of a defendant's assets are proceeds of crime and can therefore impose a confiscation order. The court will then decide the recoverable amount and make an order to repay the amount, provided that it is not disproportionate to do so. ${ }^{39}$ The civil standard of proof applies. ${ }^{40}$ Following $R v$ Summers (Michael John) $[2008]^{41}$ the defendant bears the burden of showing that his realisable assets were less than the amount he had benefited from his criminal conduct. It is thus more difficult for a defendant to avoid compliance with a confiscation order.

Recognising the impact of slavery and human trafficking on victims, section 8 of the MSA 2015 provides the power to make slavery and trafficking reparation orders. Although this power existed previously, ${ }^{42}$ few compensation orders were made under the old provisions, and so the intention behind the creation of reparation orders was to prioritise payments to victims when assets had been seized. ${ }^{43}$ The amount of compensation to be paid will be set by the court, ${ }^{44}$ cannot exceed the required amount under the confiscation order, and must take into account the defendant's means. Section $8(7)$ requires to the court to consider making such an order wherever it has the power to do so, ${ }^{45}$ but the extent to which these recent amendments have had their desired effect is difficult to determine, and research on the use of reparation orders is scarce. A comprehensive set of civil recovery powers is provided in Part V of the 2002 Act, which include recovery orders, property freezing orders, interim receiving orders, provision for seizure, detention and the forfeiture of cash, listed assets, and money in bank accounts, analysis of which is beyond the scope of this article.

\section{The broader investigative framework}

Alongside the legal provisions, the UK possesses a robust framework with regard to the financial investigation of organised crime in general. This framework, which is naturally applicable to human trafficking activities in the country, involves:

- Economic crime units that are embedded in police forces and specialised financial investigators. Apart from the use of officers from economic crime units that are embedded in police forces, ${ }^{46}$ law enforcement agencies employ specialised financial investigators that assist the main line of investigation of organised crime cases preand post-arrest. These investigators were initially trained, accredited and monitored by the National Policing Improvement Agency (NPIA), which was founded in 2007. The NPIA retained the statutory responsibility under the POCA 2002 to deliver the training, accreditation and monitoring of Financial Investigators through the

https://assets.publishing.service.gov.uk/government/uploads/system/uploads/attachment_data/file/678 000/CCS207_CCS0118810738-1_HO_POCA_COP_Search_Seizure_Detention_Accessible.pdf.

${ }^{37}$ POCA 2002 ss. 48-49.

${ }^{38}$ Ibid ss. 50-51.

${ }^{39}$ Ibid s. 6(5).

${ }^{40}$ Ibid s. 6(7).

${ }^{41}$ [2008] EWCA Crim 872.

42 (Powers of Criminal Courts (Sentencing) Act 2000).

${ }^{43}$ Hansard, HC Deb September 9, 2014: Col. 222.

${ }^{44}$ POCA 2002 s. 9(3).

${ }^{45}$ Ibid s. 9(4).

${ }^{46}$ Interview with Detective in an Organised Crime Unit, British Police, August 2017. 
Proceeds of Crime Centre (POCC); however, this function was transferred to the NCA upon the dissolution of the NPIA in 2013. In the first quarter of 2013, the total number of Financial Investigators was $673 .{ }^{47}$ POCC has also successfully upheld the Joint Asset Recovery Database (JARD), an information database implemented in 2003, maintained by the NCA, and used by approximately 4,500 users across the country. ${ }^{48}$ In addition, POCC manages the Financial Investigation Support System (FISS), which provides resources and tools for financial investigators.

- The Joint Asset Recovery Database (JARD), an information database implemented in 2003, maintained by the NCA.

- Regional Asset Recovery Teams (RARTs) established in 2004, with the very purpose to increase the numbers of confiscations and the value of assets seized. RARTs are largely multi-agency teams that provide specialist support in several aspects of financial investigation of organised crime, and among other they have the objective of targeting professional facilitators, such as solicitors/accountants.

- Public-private financial information-sharing partnerships (FISPS) that bring public agencies and major financial institutions together to tackle money-laundering (and terrorist-financing). ${ }^{49}$

\section{Financial investigation of human trafficking: prospects and challenges}

It has been established that the UK has an extensive legal framework in respect of financial investigation, and there have been successful cases involving the investigation of human trafficking through even rudimentary financial evidence. For example, an investigation may come as the result of a trafficker displaying on Facebook, for example, income of more than $£ 50,000$ per annum without him/her having the corresponding legal means to support the lifestyle. ${ }^{50}$ In other cases, financial intelligence gathered from SARs (Suspicious Activities Reports) submitted to the UK Financial Intelligence Unit (NCA), has been instrumental in instigating and supporting investigations on human trafficking. In one case in 2015, during an investigation into an OCG suspected of human trafficking, a potential victim was identified through a SAR. The subject was able to provide investigators with useful information, which confirmed that she had been trafficked by the OCG, and arrests were made. In another case in the same year, a SAR built up the profile of an individual suspected of being involved in the trafficking of women for sexual exploitation and the running of brothels. The investigation instigated by the SAR provided information about the offender making suspicious payments to hotels (bookings on behalf of clients) and receiving cash payments of unknown origin. ${ }^{51}$ In an on-going investigation looking at human trafficking and drug offences, numerous SARs have been received referring to cash credits being deposited all over the UK by individuals purporting to be studying on student visas. Around $£ 2$ million is believed to have been

\footnotetext{
${ }^{47}$ NPIA (2013) Annual Report and Accounts 2012/2013. London: The Stationery Office.

${ }^{48}$ NPIA (2013) Annual Report and Accounts 2012/2013. London: The Stationery Office.

${ }^{49}$ Maxwell, N.J. and Anrtingstall, D. (2017) The Role of Financial Information-Sharing Partnerships in the Disruption of Crime. RUSI Occasional Paper. London: RUSI.

${ }^{50}$ Interview with Detective in an Organised Crime Unit, British Police, August 2017; Interview with a Coordinator with the Regional Special Operations Unit / GAIN, July 2017.

${ }^{51}$ NCA (2015) Suspicious Activity Reports (SARs), Annual Report 2015. Available online at: http://www.nationalcrimeagency.gov.uk/publications/suspicious-activity-reports-sars/677-sarsannual-report-2015/file.
} 
transferred to other persons involved. As a result, a number of arrests have been made, over $£ 600,000$ in cash has been seized and over $£ 400,000$ restrained. $^{52}$

In some other cases financial investigation has been instrumental in the conviction of human traffickers in the UK, and money laundering cases have been prosecuted where human trafficking has been the underlying predicate offence to money laundering (although human trafficking is a predicate offence to a lesser extent than the "main proceeds-generating activities of $\left.\mathrm{OCG}^{, 53}\right){ }^{54}$ In one case, for example, a couple were fraudulently receiving child welfare benefits for a child in their care. These benefits were paid directly into the subjects' joint bank account and the subjects would then withdraw the payments in cash from an ATM. A few hours after the withdrawal of the money, the couple would deposit the amount back into the account. The financial investigation revealed that the money deposited back was the proceeds of human trafficking, and that the couple were using the bank to launder their trafficking money. After several weeks, the couple would withdraw a lump sum and transfer it overseas via a money service business. The offenders were convicted of human trafficking and money laundering. ${ }^{55}$ Despite such successful cases, there are arguably significant investigative, procedural and wider organisational challenges to the financial investigation of human trafficking. Using a range of data sources, including open and official sources, interviews with relevant law enforcement professionals as well as data emerging from participation in meetings of a regional organized crime multi-agency group, this article offers an account of these challenges as they relate to law enforcement.

\section{Scarcity of resources and expertise}

Although there is a rather robust framework, there are significant challenges to the financial investigation of human trafficking. These include, firstly, the scarcity of resources and expertise. This is an excerpt from the interview with a forensic accountant:

"There are 2 forensic accountants in Scotland... Portugal, which is only one-and-a-half times bigger than Scotland, has 30 forensic accountants. The issue is that we have to cover the set of skills that are required to deal with finances... It is ridiculous when the police officers say 'I don't feel comfortable working on finances'... And the criminal justice system as a whole needs to develop in this way. Getting prosecutors, who feel confident... yes, 'confident' is the word... and competent in dealing with financial issues is difficult. The legislation is there! The tools are there!... There is an issue there... we need to make this cultural adjustment". ${ }^{6}$

This is something that touched upon occupational law enforcement (and Criminal Justice System in general) practices and culture. The main theme that comes out of the interviews

52 NCA (2017) Suspicious Activity Reports (SARs) Annual Report 2017. Available online at: http://www.nationalcrimeagency.gov.uk/publications/suspicious-activity-reports-sars/826-suspiciousactivity-reports-annual-report-2017/file.

${ }^{53}$ E.g. Tax frauds, drug-related crimes and smuggling of high-taxed goods.

${ }^{54}$ Moneyval (2015) Typologies Report on Laundering the Proceeds of Organised Crime. Available online at:

https://www.coe.int/t/dghl/monitoring/moneyval/Activities/MONEYVAL(2015)20_typologies_laund eringtheproceedsoforganisedcrime.pdf 60; Moneyval (2005) Proceeds from Trafficking in Human Beings and Illegal Migration/Human Smuggling. Available online at: https://www.coe.int/t/dghl/monitoring/moneyval/Activities/THBTypo_Rep(2005).pdf.

${ }_{55}$ FATF/OECD (2011) Money Laundering Risks Arising from Trafficking in Human and Smuggling of Migrants. Paris: FATF 56-57.

${ }^{56}$ Interview with Head of Forensic Accountancy, British Police, August 2017. 
(and in some cases was expressed rather explicitly) is that the police are there for a specific task and this is not to be working as accountants.

\section{Focus on disruption and victims}

Although human trafficking and modern slavery is very high on the political agenda ${ }^{57}$ and the national law enforcement agenda in the UK, ${ }^{58}$ financial aspects of human trafficking are not the priority at the local level. ${ }^{59}$ The major concern is disrupting trafficking activities, and saving the victims:

"Human trafficking is a top political priority. There is a lot of pressure to deal with it internationally and nationally. But locally we get the 'good publicity' and the 'mileage' from stopping traffickers committing their crimes and saving the victims... not going after the traffickers ' money". 60

The major objective of the relevant local authorities has traditionally been to secure a trafficking conviction. This is the focal concern of law enforcement officers when dealing with trafficking, not finances. As one of the experts interviewed emphatically noted, "when a trafficking conviction is secured, why bother with finances?". ${ }^{61}$ Because of the decentralised nature of human trafficking, its relative simplicity, and the myriad of small schemes, ${ }^{62}$ there are most often no interesting financial aspects that may be necessary for a conviction to be secured.

\section{Procedural complications and delays}

Thirdly, the reluctance on the part of (local) law enforcement to engage in financial investigation of human trafficking in cases in which there might be a significant financial element is also a product of numerous practicalities. The embeddedness of many schemes of sexual and labour exploitation in legal businesses and the legal economy, makes financial aspects more complicated, law enforcement officers (perhaps with the exception of HMRC officers) uneasy and reluctant, and requires specialised investigators, who are 'expensive':

"Investigating requires some financial accounting abilities and expertise, and in cases in which significant accounting abilities are required, the officers tend to think that this is a job for the HMRC or forensic accountants... Financial investigation of human trafficking cases, just as with other cases of organised crime, falls into the trap of lengthy, complicated process. Disruption is here and now! It's quick! We should not rely on the finances to do the whole thing. We have a financial investigation team [in the police] working on organised

\footnotetext{
${ }^{57}$ In 2016, the Home Secretary, Amber Rudd, announced an $£ 11$ million Modern Slavery Innovation Fund to be awarded for projects towards identifying and disrupting human trafficking. The fund is part of $£ 33.5$ million of overseas aid funding to support the UK's leading role in tackling modern slavery internationally (Home Office, 2016).

${ }^{58}$ cf. ATMG (Anti-Trafficking Monitoring Group) (2013) In the Dock: Examining the UK's Criminal Justice Response to Trafficking. London: ATMG.

${ }^{59}$ Interview with UKHTC/NCA representative, National Crime Agency, July 2017; Interview with Head of Cyber Crime Team, British Police, August 2017.

${ }^{60}$ Interview with Detective in an Organised Crime Unit, British Police, August 2017.

${ }^{61}$ Interview with UKHTC/NCA representative, National Crime Agency, July 2017.

${ }^{62}$ See also Shentov, O., Rusev, A. \& Antonopoulos, G.A. (eds) (2019) Financing of Organised Crime: Human Trafficking in Focus. Sofia: Centre for the Study of Democracy
} 
crime cases and human trafficking... but you reach at a certain point when a forensic accountant will be needed and this is very, very, very expensive...". ${ }^{63}$

The financial investigation of human trafficking is also considered a very lengthy process and a 'procedural nightmare' especially when financial institutions' (e.g. banks) contribution in the form of evidence/statements is required. ${ }^{64}$ These financial institutions are rather reluctant to provide the necessary evidence for cases that do not proceed to court. ${ }^{65}$ As Hutton notes, ${ }^{66}$ the confiscation and financial sections of the cases dealt with by the Metropolitan Police very often stretch for years and in many cases the human traffickers serve their sentence and are released before the end of the confiscation proceedings.

\section{Low efficiency}

A financial investigation into human trafficking does not often produce results commensurate to the effort and resources invested by law enforcement. ${ }^{67}$ Operation 'Pentameter 2', launched in October 2007, for example, was a joint national venture that involved all police forces in the UK, SOCA, the UK Immigration Service, the Crown Prosecution Service and several NGOs. The operation resulted in 528 traffickers arrested, and "more than $£ 500,000$ worth of cash [...] recovered from those criminals arrested". ${ }^{8}$ If, for the economy of the argument, we accept that the cash seized amounts to $£ 550,000$, the cash seized per trafficker was an average of £1041.66. Sproat has analysed British Ministry of Justice figures on Confiscation Orders placed on sentenced human traffickers for the period 2004-2009. ${ }^{69}$ These figures show that nearly $90 \%$ of the traffickers were not even issued a Confiscation Order, which made Sproat offer a plausible explanation: human traffickers "had so few assets [and] the Police/CPS did not even bother trying!". ${ }^{70}$ This is echoed in one of the interviewee's accounts suggesting that when it comes to organised crime, human traffickers in the UK are not financially interesting compared to other organised criminals, who are the priority of financial investigation, such as drug smugglers:

"Financially speaking human traffickers, at least the ones in the UK, are at the bottom of the 'food chain' of organised criminals. Drug dealers are at the top. It is the drug dealers' Lamborghinis and Porsches the government and the public want us to go after..." ${ }^{71}$

It is perhaps relevant to note here that, according to Bullock et al., who examined JARD data, in 2006/07 62\% of confiscation orders were made for offences of 'drug trafficking' followed

\footnotetext{
${ }^{63}$ Interview with Senior Police Officer / Organised Crime Unit, British Police, July 2017.

${ }^{64}$ Interview with Senior Police Officer / Organised Crime Unit, British Police, July 2017; Interview with a Coordinator with the Regional Special Operations Unit / GAIN, July 2017.

${ }^{65}$ see Brown, R., Evans, E., Webb, S., Holdaway, S. Berry, G., Chenery, S. Gresty, B. and Jones, M. (2012) The Contribution of Financial Investigation to Tackling Organised Crime: A Qualitative Study. Research Report 65 London: Home Office.

${ }^{66}$ Hutton, S. (2017) Organised Crime: An Ethnographic Study of the Monitoring and Disrupting of those Designated as High-Level 'Organised Criminals' Within the Metropolitan Police. Unpublished $\mathrm{PhD}$ thesis, Open University.

${ }^{67}$ Interview with an Official, Strategic Centre for Organised Crime, Home Office, August 2017;

Interview with a Coordinator with the Regional Special Operations Unit / GAIN, July 2017.

${ }^{68}$ Home Office (2008) 'Major Police Probe into Trafficking Lead to 528 Arrests', Home Office News Release, $124 / 2008$.

${ }^{69}$ Sproat, P. (2012) 'A Critique of the Official Discourse on Drug and Sex Trafficking by Organised Crime Using Data on Asset Recovery', Journal of Financial Crime, 19(2), 149-162.

${ }^{70}$ Ibid 156.

${ }^{71}$ Interview with Detective in an Organised Crime Unit, British Police, August 2017.
} 
by fraud/deception ( $10 \%$ of orders), burglary/theft ( $7 \%$ of orders), and VAT fraud ( $0.5 \%$ of orders). With regard to their value, confiscation orders with the highest mean values were VAT frauds ( $£ 336,000)$, followed by money laundering offences $(£ 255,000)$, robbery $(£ 21,500)$, drug trafficking $(£ 20,000)$, and burglary/theft $(£ 14,500) .{ }^{72}$ Human trafficking did not feature in the analysis. ${ }^{73}$ Moreover, in a Home Office study, Brown et al. selected a number of cases that had a confiscation order assessed benefit value of $£ 100,000$ or more in order to identify the more serious cases, which were also considered most likely to relate to 'organised' criminality. Of those, the percentage of cases that could possibly (but not necessarily) be 'human trafficking-related' were only 5\% for 'prostitution' (3 cases) and 7\% for 'immigration offences' (4 cases). ${ }^{74}$ The reasons for the small reported proceeds of trafficking may be a result of the actual small profits for traffickers given the human trafficking in the UK is a purely competitive market, the fact that the most significant part of the business is cash-based, which makes the tracing of money extremely difficult, and the fact that payments are often made in source and transit countries. Of course, one needs to bear in mind that it is impossible for the authorities to differentiate between those human traffickers, who have simply spent their crime money and those who have successfully hidden their assets in other contexts. For instance, MX, a Chinese 'madam' exploiting trafficking victims in Hutton's study, ${ }^{75}$ transferred significant amounts of money to China and Malaysia.

\section{Conclusion}

Combining the substantive and financial investigation of Human Trafficking has theoretical advantages: it can potentially uncover the extended network, activities, associates, geographical reach, and importantly, it may proactively identify traffickers' assets to be seized/confiscated. While there is always room for improvement, and the government has already indicated that it is conducting an independent review into the Modern Slavery Act, ${ }^{76}$ this research has not found the legal framework of Human Trafficking itself to be wanting. Powers to investigate, restrain, seize, search and confiscate assets exist and can be deployed.

In reality, however, these theoretical advantages are diluted by practical considerations as the outlook of human trafficking does not lend itself well to financial investigation. Many of the human trafficking schemes are embedded in legitimate business whereas most of the trafficking schemes are simple in nature and small. ${ }^{77}$ Thus, the theoretical advantages of financial investigation are contingent upon the social organisation, structure and size of the

${ }^{72}$ Bullock, K., Mann, D., Street, R. and Coxon, C. (2009) Examining attrition in confiscating the proceeds of crime. Available online at: http://library.college.police.uk/docs/horr/horr17c.pdf.

${ }^{73}$ Bullock, K. (2014) 'Criminal Benefit, the Confiscation Order and the Post-Conviction Confiscation Regime', Crime, Law and Social Change, 62(1), 45-64.

${ }^{74}$ Brown, R., Evans, E., Webb, S., Holdaway, S. Berry, G., Chenery, S. Gresty, B. and Jones, M. (2012) The Contribution of Financial Investigation to Tackling Organised Crime: A Qualitative Study. Research Report 65 London: Home Office.

${ }^{75}$ Hutton, S. (2017) Organised Crime: An Ethnographic Study of the Monitoring and Disrupting of those Designated as High-Level 'Organised Criminals' Within the Metropolitan Police. Unpublished $\mathrm{PhD}$ thesis, Open University.

${ }^{76}$ Home Office (2018) Guidance: Review of the Modern Slavery Act 2015: terms of reference.

Available online at: https://www.gov.uk/government/publications/modern-slavery-act-2015independent-review-terms-of-reference/review-of-the-modern-slavery-act-2015-terms-of-reference.

${ }^{77}$ See also Shentov, O., Rusev, A. \& Antonopoulos, G.A. (eds) (2018) Financing of Organised Crime: Human Trafficking in Focus. Sofia: Centre for the Study of Democracy. 
illegal market associated with human trafficking - and arguably any illegal market. In the case of human trafficking, this entails that while some significant amounts have been laundered in specific cases, sophisticated laundering schemes are the exception rather than the rule in the UK. The management of profits from human trafficking reflects primarily the fragmented nature of the phenomenon, the relatively small size of most schemes, the financial abilities of the criminal entrepreneurs and level of embeddedness of a trafficking scheme in a legal business. Investments are modest (reflecting in most cases the modest profits made in a rather open and highly competitive business). Despite the vast and wellintentioned legal framework, confiscation, seizure and compensation are much less preferred weapons to combat against human trafficking. Aiming to tangibly and quickly disrupt the activity, investigative authorities continue to rely on older, more established and better known methods.

\section{References}

Antonopoulos, G.A. \& Hall, A. (2016) 'The Financial Management of the Illicit Tobacco Trade in the United Kingdom', British Journal of Criminology, 56(4), 709-728

ATMG (Anti-Trafficking Monitoring Group) (2013) In the Dock: Examining the UK's Criminal Justice Response to Trafficking. London: ATMG

Brown, R., Evans, E., Webb, S., Holdaway, S. Berry, G., Chenery, S. Gresty, B. and Jones, M. (2012) The Contribution of Financial Investigation to Tackling Organised Crime: A Qualitative Study. Research Report 65 London: Home Office

Bullock, K. (2014) 'Criminal Benefit, the Confiscation Order and the Post-Conviction Confiscation Regime', Crime, Law and Social Change, 62(1), 45-64

Bullock, K., Mann, D., Street, R. and Coxon, C. (2009) Examining attrition in confiscating the proceeds of crime. Available online at: http://library.college.police.uk/docs/horr/horr17c.pdf

Centre for the Study of Democracy (2015) Financing of Organised Crime. Sofia: Centre for the Study of Democracy

Dubourg, R., \& Prichard, S. (2008). Organised crime: revenues, economic and social costs, and criminal assets available for seizure. London: Home Office

FATF/OECD (2011) Money Laundering Risks Arising from Trafficking in Human and Smuggling of Migrants. Paris: FATF

Hansard, HC Deb September 9, 2014: Col. 222

HM Government, 2014, 'Modern Slavery Strategy 2014'; available online at https://www.bl.uk/collection-items/modern-slavery-strategy.

HM Government (2015) Report of the inter-departmental ministerial group on modern slavery 2015 London: HMSO 
HM Government (2018), 2018 UK Annual Report on Modern Slavery. Available online at: https://assets.publishing.service.gov.uk/government/uploads/system/uploads/attachment_data /file/749346/2018_UK_Annual_Report_on_Modern_Slavery.pdf 62.

Home Office (2008) 'Major Police Probe into Trafficking Lead to 528 Arrests', Home Office News Release, 124/2008

Home Office (2016) 'Home Secretary pledges $£ 11$ million for groups fighting modern slavery'. Available online at: https://www.gov.uk/government/news/home-secretary-pledges11-million-for-groups-fighting-modern-slavery

Home Office (2018) 'CODE OF PRACTICE ISSUED UNDER SECTION 47S OF THE PROCEEDS OF CRIME ACT 2002 Search, Seizure and Detention of Property (England and Wales)'. Available online at https://assets.publishing.service.gov.uk/government/uploads/system/uploads/attachment_data /file/678000/CCS207_CCS01188107381_HO_POCA_COP_Search_Seizure_Detention_Accessible.pdf

Home Office (2018) Guidance: Review of the Modern Slavery Act 2015: terms of reference. Available online at: https://www.gov.uk/government/publications/modern-slavery-act-2015independent-review-terms-of-reference/review-of-the-modern-slavery-act-2015-terms-ofreference.

Hutton, S. (2017) Organised Crime: An Ethnographic Study of the Monitoring and Disrupting of those Designated as High-Level 'Organised Criminals' Within the Metropolitan Police. Unpublished PhD thesis, Open University

Levi, M. and Osofsky, L. (1995) Investigating, Seizing and Confiscating Proceeds of Crime. London: Home Office

Levi, M. (2013) Drug Law Enforcement and Financial Investigation Practices. London: IDPC

Maxwell, N.J. and Anrtingstall, D. (2017) The Role of Financial Information-Sharing Partnerships in the Disruption of Crime. RUSI Occasional Paper. London: RUSI

May, T. (2016) 'My Government will lead the way in defeating modern slavery ', The Telegraph, July 30,

Mills, H., Skodbo, S., \& Blyth, P. (2013) Understanding organised crime: estimating the scale and the social and economic costs. London: Home Office

Moneyval (2005) Proceeds from Trafficking in Human Beings and Illegal Migration/Human Smuggling. Available online at:

https://www.coe.int/t/dghl/monitoring/moneyval/Activities/THBTypo_Rep(2005).pdf

Moneyval (2015) Typologies Report on Laundering the Proceeds of Organised Crime. Available online at:

https://www.coe.int/t/dghl/monitoring/moneyval/Activities/MONEYVAL(2015)20_typologie s launderingtheproceedsoforganisedcrime.pdf 
NCA (2015) Suspicious Activity Reports (SARs), Annual Report 2015. Available online at: http://www.nationalcrimeagency.gov.uk/publications/suspicious-activity-reports-sars/677sars-annual-report-2015/file

NCA (2017) Suspicious Activity Reports (SARs) Annual Report 2017. Available online at: http://www.nationalcrimeagency.gov.uk/publications/suspicious-activity-reports-sars/826suspicious-activity-reports-annual-report-2017/file

NPIA (2013) Annual Report and Accounts 2012/2013. London: The Stationery Office

Shentov, O., Rusev, A. \& Antonopoulos, G.A. (eds) (2018) Financing of Organised Crime: Human Trafficking in Focus. Sofia: Centre for the Study of Democracy

Sproat, P. (2012) 'A Critique of the Official Discourse on Drug and Sex Trafficking by Organised Crime Using Data on Asset Recovery', Journal of Financial Crime, 19(2), 149162

Sproat, P. (2018) 'Unexplained wealth orders: an explanation, assessment and set of predictions', Journal of Criminal Law, 82(3), 232-244.

The Independent (2017) 'Human trafficking and slavery affecting 'every large town and city in UK', The Independent, August 10

van Duyne, P.C. \& Levi, M. (2005) Drugs and Money. London: Routledge 